medRxiv preprint doi: https://doi.org/10.1101/2021.07.25.21260967; this version posted July 28, 2021. The copyright holder for this preprint

(which was not certified by peer review) is the author/funder, who has granted medRxiv a license to display the preprint in perpetuity.

All rights reserved. No reuse allowed without permission.

\title{
Influence of Novel Coronavirus COVID - 19 and HIV: A Scoping Review of Hospital Course and Symptomatology
}

Mona Sheikh, MD*., Shavy Nagpal, MD**, Madiha Zaidi, MD. Rupalakshmi Vijayan, MD. Wanessa Matos, MD. Neguemadji Nagardig Ngaba, MD. Lordstrong Akano, MD. Samia Jahan, MD. Shazia Q. Shah, MD. Camille Celeste Go, MD., Sindhu Thevuthasan, George Michel MD

Conflicts of interest - None of the authors have reported any conflicts of interest.

Funding - There is no financial disclosure related to this study.

Acknowledgments - Krunal Pandav, MD; Sumedh Keul, statistician, Larkin Research Department, Miami, Florida

Keywords: HIV, COVID-19, Mortality, SARS-CoV-2, Coronavirus

** corresponding - Department of Surgery, The Research Institute of St. Joe's Hamilton, ON, Canada, shav.nagpal@gmail.com

*arztinmona@gmail.com - Department of Medicine, Larkin Community Hospital South Miami, Florida, US

Abbreviations: HIV - Human immunodeficiency virus, ART - Antiretroviral therapy, ICU - Intensive care unit, PLWH - People living with HIV, +ssRNA - positive single stranded RNA, SOB - shortness of breath, HTN -hypertension, DM - diabetes mellitus, CKD - chronic kidney disease, COPD - chronic obstructive pulmonary disease, CVD - cardiovascular disease, HLD - hyperlipidemia, HBV - hepatitis B virus, HCV hepatitis $C$ virus, CAD - coronary artery disease, ESRD - end stage renal disease, NASH - non-alcoholic steatohepatitis, OSA - obstructive sleep apnea, CHF - congestive heart failure, TB - tuberculosis.

\begin{abstract}
:
Background: An outbreak of novel coronavirus (SARS- CoV-2) was observed on December 2019 in Wuhan, China which led to a global pandemic declared in March 2020. As a consequence, it imposed delirious consequences in patients with underlying co-morbid conditions that make them immunocompromised. The purpose of this paper is to provide an in - depth review of influence of COVID - 19 in patients with underlying HIV in terms of mortality and hospitalization.
\end{abstract}

Authors also aim to provide a thorough risk analysis of hospitalization, ICU admission and mortality of PLWH and COVID-19. The secondary objective was to analyze the CD4+ count variations and outcome of COVID - 19 and to correlate if ART provided a protective role. Authors also aim to provide an evaluation of typical clinical presentation of COVID-19 in PLWH. ART is found to show activity against SARS-CoV-2 in vitro, and there is some similarity in the structure of HIV-1 gp41 and S2 proteins of SARS-CoV since they both belong to +ssRNA type.

Methods: We conducted a literature review using search engines namely, Cochrane, PubMed and Google Scholar. The following keywords were targeted: "COVID-19," "SARS-CoV-2," and "HIV." We included case reports, case series, and cohort (retrospective and prospective) studies. We excluded clinical trials and review articles. We came across 23 articles that met the inclusion criteria. PRISMA guidelines were followed for study acquisition (Fig. 9). 
medRxiv preprint doi: https://doi.org/10.1101/2021.07.25.21260967; this version posted July $28,2021$. The copyright holder for this preprint (which was not certified by peer review) is the author/funder, who has granted medRxiv a license to display the preprint in perpetuity.

All rights reserved. No reuse allowed without permission.

Results: From the 23 studies, we found a total of 651 PLWH with confirmed COVID-19 $(549,91$, and 11 in cohorts, case series, and case reports, respectively). The overall risk of hospital admission from pooled data of the 23 reviewed articles was 69.13\% (450/651), ICU admission was 12.90\% (84/651) in total infected patients, and $18.67 \%$ (84/450) among hospitalized patients. The overall case fatality rate from the 23 reviewed articles was 11.21 (73/651).A weak positive correlation was found between CD4+ counts and hospital admissions in case series and case reports, while the weak negative correlation was found in cohorts. For mortality, there was a negative weak association in the cohorts and in case series, while a weak positive was seen in case reports (Fig.7). We assessed the presenting symptoms of PLWH with COVID-19, and our review demonstrated this group does not greatly differ from the rest of the population, as their common presenting symptoms were cough, fever, and SOB.

Conclusion: Our results indicated that there was a high rate of hospitalization, ICU admission, and mortality among patients living with HIV and COVID-19. PLWH needs to be noted as a high-risk group for COVID-19 complications and severity. We recommend that PLWH be closely monitored by their physicians and strictly adhere to antiretroviral therapy and standard universal COVID-19 precautions.

\section{Fig.7 Results: As scoping review of HIV and COVID-19}

\section{Reviewed articles}

$80.00 \%$

$70.00 \%$

$60.00 \%$

$50.00 \%$

$40.00 \%$

$30.00 \%$

$20.00 \%$

$10.00 \%$

$0.00 \%$

\section{Introduction:}

SARS-CoV-2 is a member of $\beta$-CoVs (Fig. 8) and is a global concern at present. What interests Authors were the overlapping similarities between the Human Immunodeficiency Virus (HIV) and SARS-COV-2 virus in terms of same RNA single-stranded family and protein structural motifs of HIV-1 gp41 and SARS-CoV-S2 [9]. Having said that, it was proposed in clinical trials to implement ART as a treatment modality for COVID - 19. However, it is not recommended by the Treatment Guidelines Panel for COVID-19 yet [10].

The prognosis of COVID-19 in common comorbidities such as HTN, DM and CVD is well known but its prognosis or outcome of patients living with HIV is not well understood so far (Ssentongo et al, 2020) [11]. This review article focuses on the people living with HIV which are confirmed COVID-19 positive cases. 
medRxiv preprint doi: https://doi.org/10.1101/2021.07.25.21260967; this version posted July $28,2021$. The copyright holder for this preprint (which was not certified by peer review) is the author/funder, who has granted medRxiv a license to display the preprint in perpetuity.

All rights reserved. No reuse allowed without permission.

The main focus of our review is to assess the risk of hospitalization, intensive care unit (ICU) admission, invasive mechanical ventilation (IMV) requirement and mortality in persons living with HIV (PLWH) who were COVID-19 positive. The secondary objective is to assess whether any correlation exists between CD4+ count and COVID-19 in PLWH with the third objective to evaluate the typical clinical presentation of COVID-19 in such patients.

Fig. 8 SARS-CoV-2 (Ref. 2- 10)

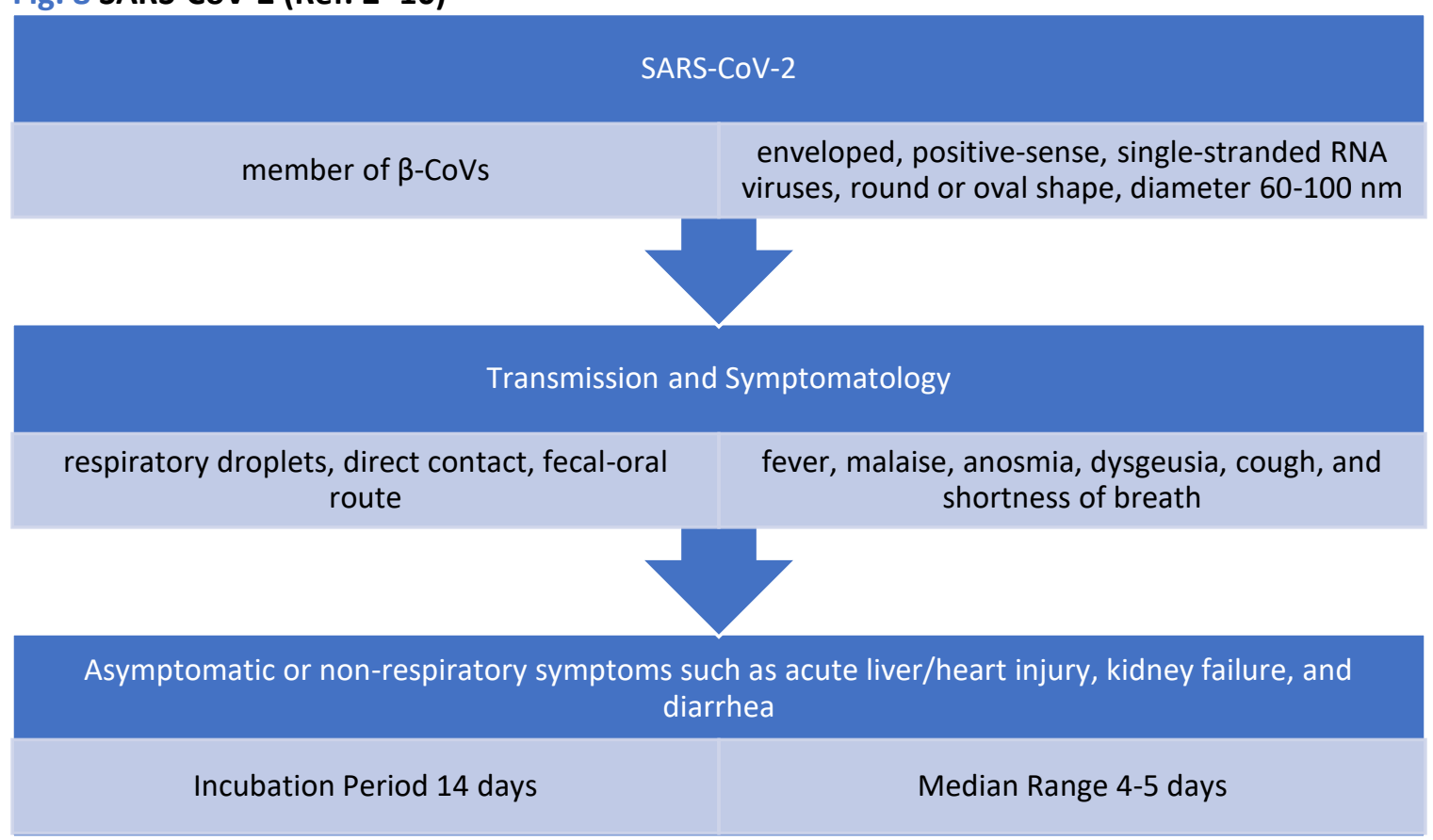

\section{Methods:}

\section{Literature search}

A literature search was conducted with PubMed, Cochrane, and Google scholars using the following keywords: "COVID-19", "HIV," "SARS-CoV-2", and "AIDS" from January 2020 until August 31st, 2020. Only papers in English language were considered. PRISMA guidelines were followed (Fig. 9).

\section{Inclusion \& Exclusion criteria and study selection}

The case reports, case series, retrospective cohort studies and prospective cohort studies published between January 1, 2020, and August 31, 2020 with data of PLWH and confirmed COVID-19 by RT-PCR were included in our review. Review articles, clinical trials, and preprint articles were excluded. Articles that did not have patient data and those limited to specific comorbidities and organ dysfunctions were also excluded to avoid selection bias.

We narrowed it down to 48 articles that were screened based on the relevancy of the titles and abstracts. We excluded 32 articles, of which 20 did not meet the inclusion criteria, 2 required access, and 3 were not peer-reviewed. We included 23 studies in this paper. Selected articles were independently reviewed by two authors. All disagreements were resolved with a discussion between the two authors or with input from a third independent reviewer and mutually agreed upon by the authors.

\section{Data Extraction}

The authors designed a predefined data extraction list to be used to extract the required data from the included studies. The following data were extracted: First author's name, publication date, study design, 
medRxiv preprint doi: https://doi.org/10.1101/2021.07.25.21260967; this version posted July 28, 2021. The copyright holder for this preprint (which was not certified by peer review) is the author/funder, who has granted medRxiv a license to display the preprint in perpetuity. All rights reserved. No reuse allowed without permission.

country, the total number of PLWH with confirmed COVID-19 by RT-PCR or antigen test, age, gender, comorbidities, ART, CD4+ cell counts, viral load, number of hospitalized patients (age, gender), duration of hospitalization, number admitted to ICU, a number that needed IMV and number of deaths (age, gender, comorbidity, CD4+ counts, ART list).

\section{Data collection and Analysis}

The data was collected on excel sheets and Google documents. We ran a qualitative review based on our primary and secondary outcomes. The studies used have been listed in Table 1-3. The data were tabulated using Microsoft Excel.

The Pearson correlation coefficient was used to assess the correlation between CD4+ counts and hospitalization and mortality, and the association of COVID-19 infection with hospital admission. A P-value $<0.05$ was considered significant and was calculated by using R factor, Z score and standard deviation.

\section{Ethical approval and funding}

We did not seek IRB approval, as our study is based on data from published articles and patients were not directly involved. No funding was obtained for this review.

\section{Fig.9 PRISMA guidelines for study acquisition}


medRxiv preprint doi: https://doi.org/10.1101/2021.07.25.21260967; this version posted July 28, 2021. The copyright holder for this preprint (which was not certified by peer review) is the author/funder, who has granted medRxiv a license to display the preprint in perpetuity.

All rights reserved. No reuse allowed without permission.

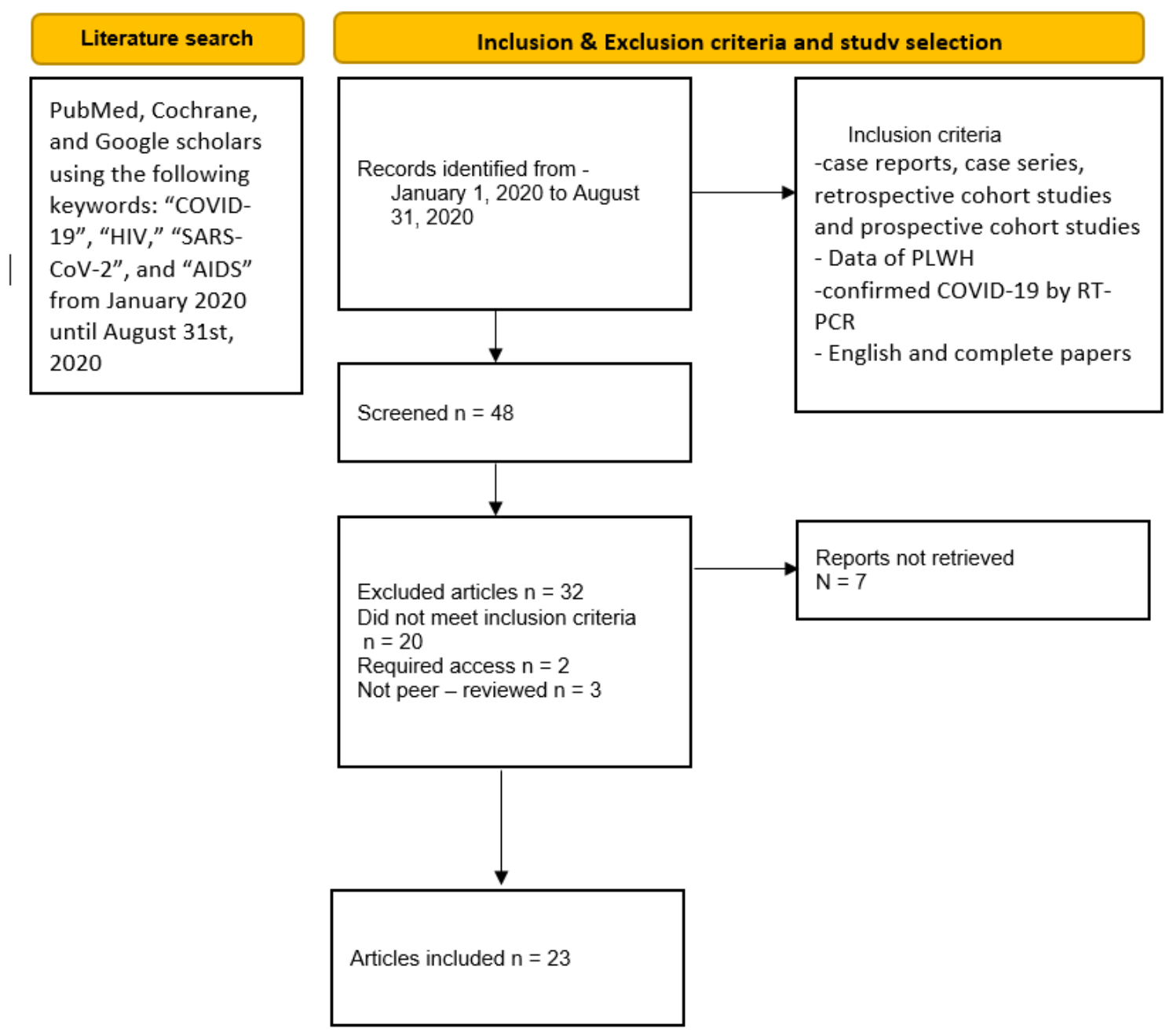

\section{Results:}

This review included a total of 23 articles after excluding those that did not meet the inclusion criteria (20), not peer reviewed (3), and required access (2). The 23 articles were 7 cohort studies, 7 case series, and 9 case reports; (Fig. 10) and they were from different countries: USA (9), China (4), Spain (3), Italy (2), the UK (1), Germany (1), Turkey (1), India (1), Japan (1) and Uganda (1) (Fig. 11)

Our review was categorized into three groups based on the similarity of study type: which are cohort group (Ch), case series group (CS), and case report group (CR). The number of PLWH and confirmed COVID19 were 549 from cohort studies (Ch), 91 from case series (CS), and 11 from case reports (CR). The mean age (in years) were 54 in Ch, 45 in CS, and 36 in CR. The gender distribution in the Ch was 440 male, 106 female, and 3 transgender; in CS was 62 male, 25 female, and 3 transgender; and in CR was 8 males and 3 females. [Tables 1-3]

Fig. 10 Types of included studies 


\section{REVIEWED ARTICLES}

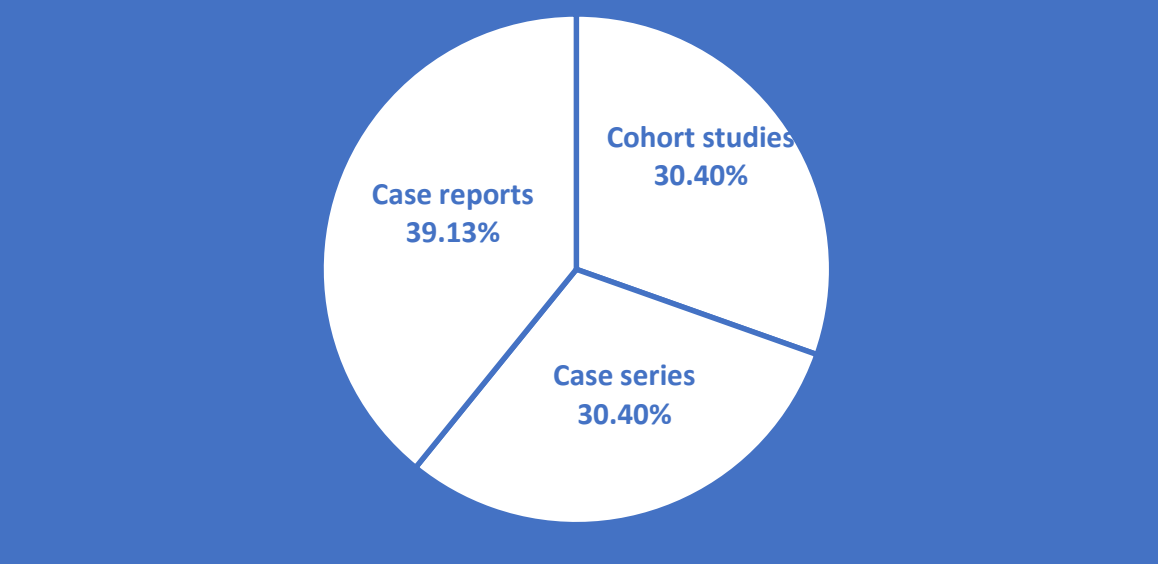

Fig. 11 Geographical location of included studies

\section{Geographical location of included studies}

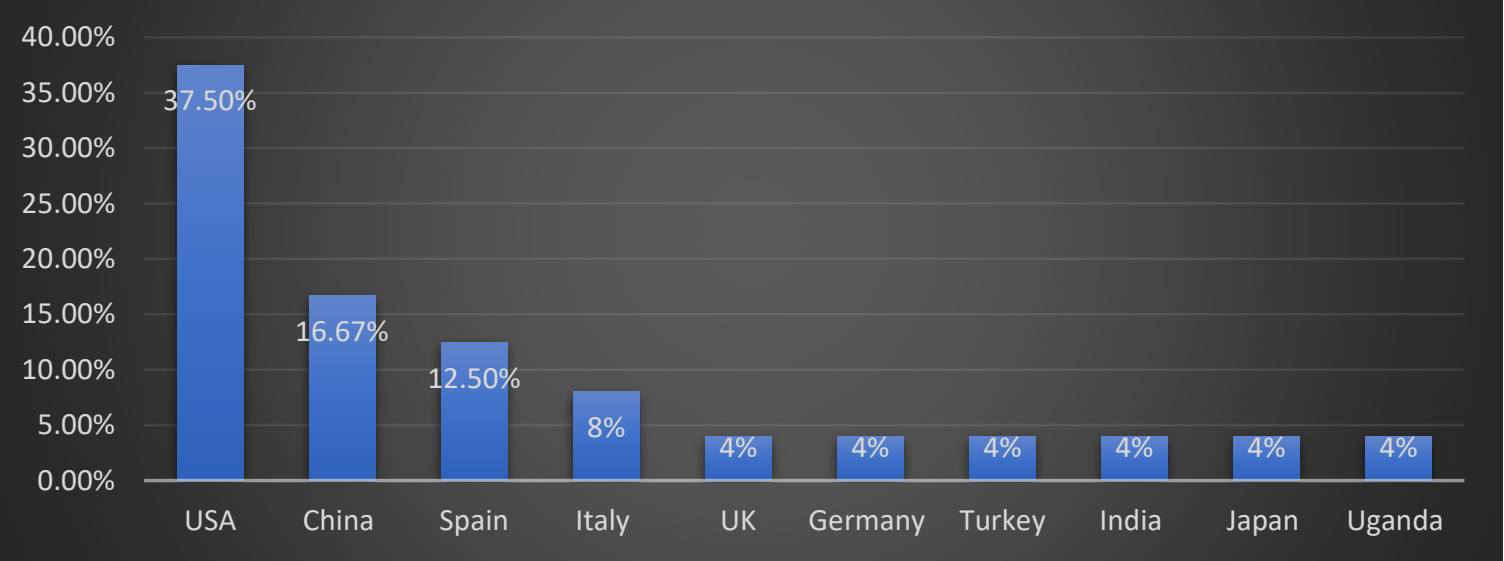

\section{Risk of hospitalization of PLWH + confirmed COVID-19}

The total number of hospitalized patients were $387 \mathrm{in} \mathrm{Ch,} 52$ in CS, and 11 in CR. The risk of hospitalization in these 3 groups were $70.49 \%$ (387/549) in Ch, 57.14\% (52/91) in CS, and 100\% in CR. [Table 1-3] The overall risk of hospital admission from pooled data of the 23 reviewed articles was $69.13 \%$ (450/651).

\section{Risk of ICU admission among hospitalized patients}

The number of patients that needed critical care were 72 in Ch, 9 in CS, and 3 in CR. The calculated risk among hospitalized patients was $18.61 \%(72 / 387)$ in Ch, $17.31 \%(9 / 52)$, and $27.27 \%(3 / 11)$ in CR. [Table 1-3] The overall risk of ICU admission from pooled data of the 23 reviewed articles was $12.90 \%$ (84/651) in total infected patients and $18.67 \%(84 / 450)$ among hospitalized patients.

\section{The risk of IMV requirement in hospitalized and ICU patients}

Of those patients who were admitted to the ICU: 48 in Ch, 9 in CS, and 2 patients in CR needed invasive mechanical ventilation (IMV). The risk among hospitalized and ICU patients was $(12.7 \%, 66.67 \%)$ in $\mathrm{Ch}$, $(13.46 \%, 77.78 \%)$ in CS, and $(18.18 \%, 66.67 \%)$ in CR. [Table 1-3] 
medRxiv preprint doi: https://doi.org/10.1101/2021.07.25.21260967; this version posted July 28, 2021. The copyright holder for this preprint (which was not certified by peer review) is the author/funder, who has granted medRxiv a license to display the preprint in perpetuity. All rights reserved. No reuse allowed without permission.

The mortality rate of PLHW + confirmed COVID-19

The total number of deaths in the three categories was 66 in Ch, 6 in CS, and 1 CR, respectively. The case fatality rate was $12.02 \%(66 / 549)$ in $\mathrm{Ch}, 6.59 \%(6 / 91)$ in CS, and $9.09 \%(1 / 11)$ in CR [Tables 1 3]. The overall case fatality rate from the 23 reviewed articles was $11.21(73 / 651)$

\section{Correlation of $C D+$ counts with hospitalization and mortality}

The Pearson Correlation coefficient was used to assess the association of CD4+ counts with hospitalization and mortality in PLWH+COVID-19. A weak positive correlation was found between CD4+ counts and hospital admissions in case series ( $r=0.2622$, $p$-value $=0.089403)$ (Fig. 1$)$ and case reports $(r$ $=0.2269$, $p$-value $=0.5284)$ (Fig. 2), while the weak negative correlation was found in cohorts $(r=-0.114$, $p$-value $=0.043866)$ (Fig. 3). For the mortality correlation, there was a negative weak association in the cohorts ( $r=-0.1218, p$-value $=0.031)($ Fig. 4) and in case series $(r=-0.011, p$-value $=0.986)($ Fig. 5$)$, while a weak positive was seen in case reports $(r=0.0667)$ (Fig. 6).

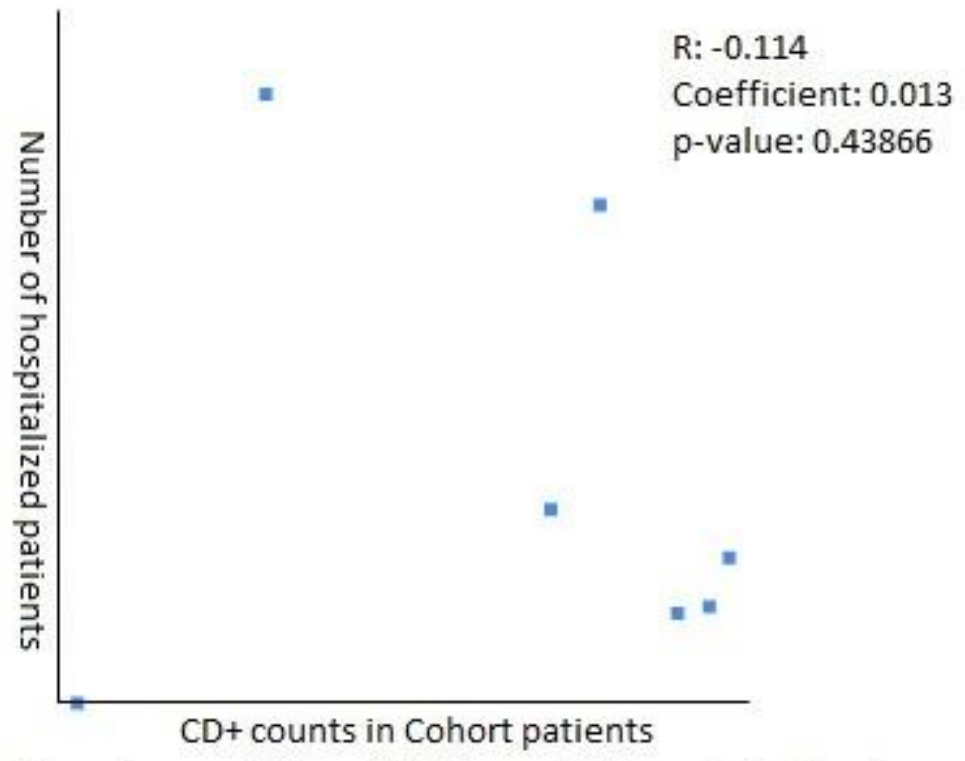

Figure 1. correlation of CD4+ counts \& hospitalization in cohorts patients 
medRxiv preprint doi: https://doi.org/10.1101/2021.07.25.21260967; this version posted July 28, 2021. The copyright holder for this preprint (which was not certified by peer review) is the author/funder, who has granted medRxiv a license to display the preprint in perpetuity. All rights reserved. No reuse allowed without permission.

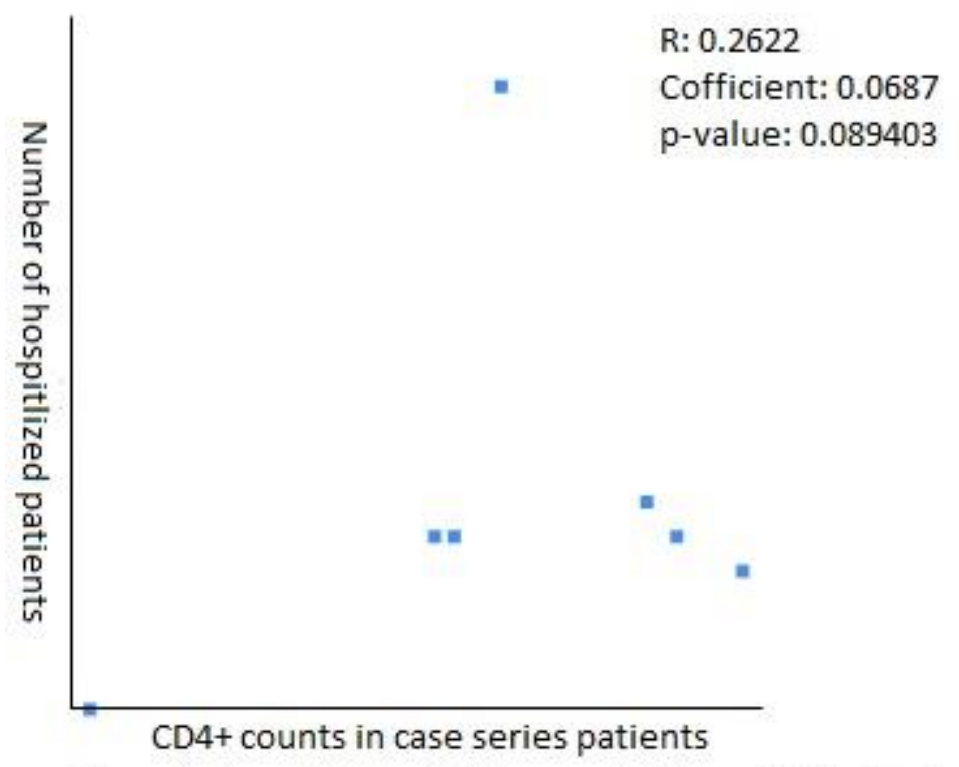

Figure 2. Correlation of $\mathrm{CD} 4+$ counts $\%$ hospitalization in case series

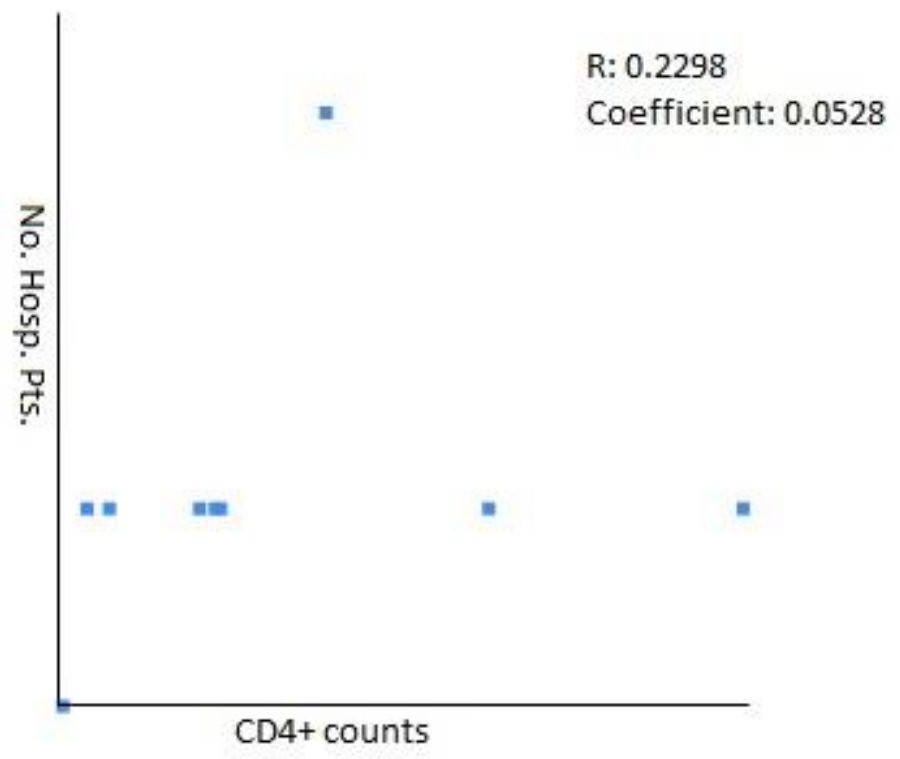

Figure 3: Correlation of CD4+ counts \& hospitalization in Case Reports 
medRxiv preprint doi: https://doi.org/10.1101/2021.07.25.21260967; this version posted July 28, 2021. The copyright holder for this preprint (which was not certified by peer review) is the author/funder, who has granted medRxiv a license to display the preprint in perpetuity. All rights reserved. No reuse allowed without permission.

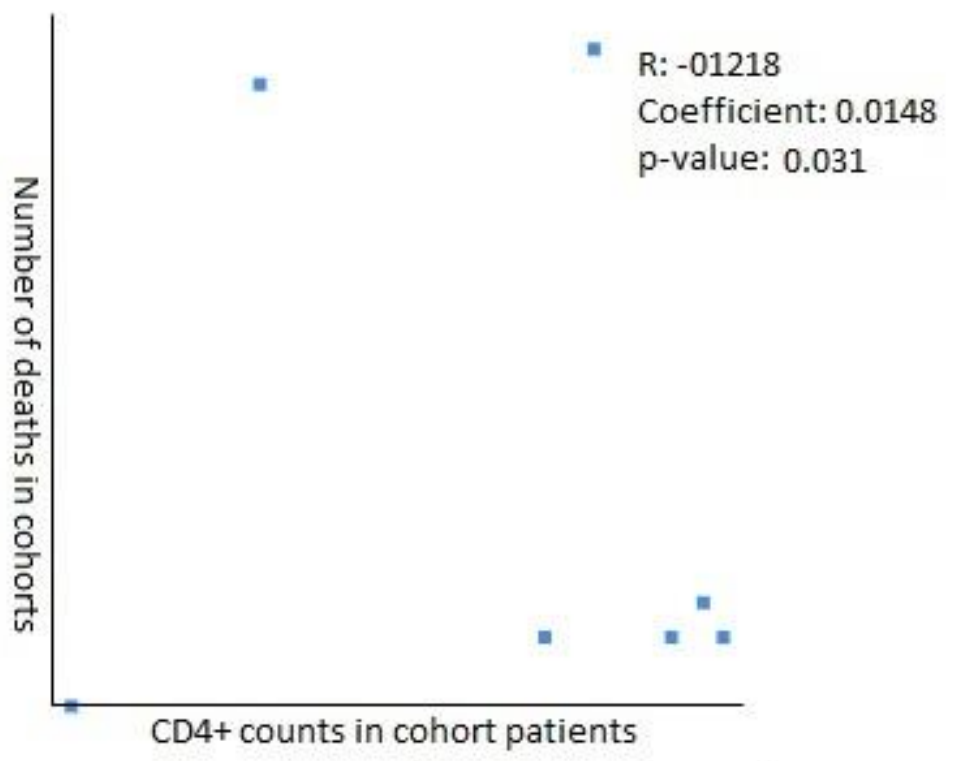

Figure 4. Correlation of CD4+ counts \& Mortality in cohorts

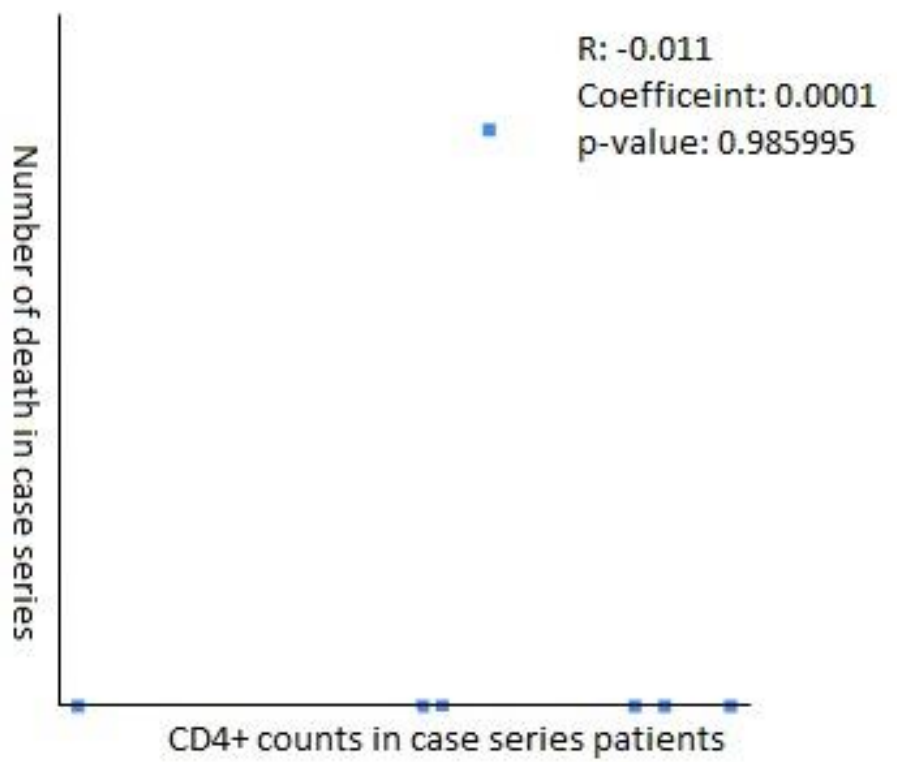

Figure 5. Correlation of CD4+ counts \& Mortality in Case series 


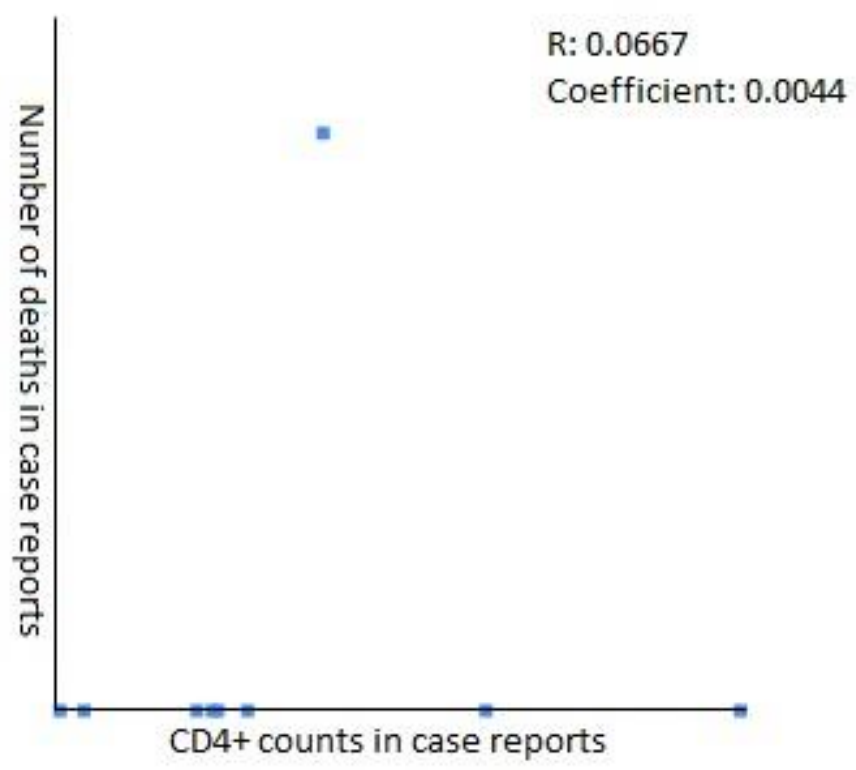

Figure 6. Correlation of CD4+ counts \& Mortality in case reports

\section{Clinical presentations in PLWH + COVID-19}

The clinical presentation from the pooled data of the 23 articles was available for 319 patients. The most common symptoms among these patients were cough $(57.4 \%, \mathrm{no}=183)$, fever $(55.5 \%, \mathrm{no}=177)$, SOB $(21.9 \%$, no $=70)$, myalgia $(13.2 \%$, no $=42)$, fatigue $(11.9 \%$, no $=38)$, and headache $/$ malaise $(11 \%$, no= $35)$. And least common with less than $10 \%$ were dyspnea $(9.7 \%$, no $=31)$, gastrointestinal symptoms (nausea/vomiting/diarrhea) $(6.6 \%, \mathrm{no}=21)$, sore throat $(6.3 \%, \mathrm{no}=20)$, anosmia/ageusia $(4.4 \%, \mathrm{no}=14)$, and altered mental status $(4.4 \%$, no $=14)$ [Table 5$]$.

\section{Co-morbidities in COVID positive PLWH groups}

The comorbidities from the 23 articles were reported for 417 out of 649 patients; of which the most common chronic medical conditions found were hypertension $(37.4 \%, \mathrm{no}=156)$, diabetes mellitus $(21.8 \%$, no $=91)$, chronic kidney disease $(12.2 \%$, no $=51)$, COPD/asthma/lung disease $(12.2 \%$, no= 51$)$, cancer $(8.9 \%$, no $=37)$, obesity $(6.7 \%$, no $=28)$, cardiovascular disease $(6.2 \%, \mathrm{no}=26)$, chronic liver disease $(5.5 \%$, no= 23), and hyperlipidemia $(5.8 \%$, no $=24)$ [Table 5]

\section{Discussion:}

We conducted a systematic quantitative review to evaluate certain aspects of COVID-19 in patients living with human immunodeficiency virus (PLWH). The outcomes were categorized into risk of hospitalization, ICU admission, IMV requirement and mortality. The review of 23 articles indicated that there was a consistent high risk of hospitalization, ICU admission, IMV requirement and mortality in PLWH + confirmed COVID-19-positive in the cohort studies, case series and case reports. The rate of hospitalization from the pooled data of the 3 groups (Ch, CS, Cr) was 69.13\% ( $n=450) ; 70.49 \%$ in Ch [12-18], $57.14 \%$ in CS [19-25], and $100 \%$ in CR [26-34]. The rate of ICU admission was $12.9 \%(n=84)$ for the 3 groups; $18.61 \%$ in Ch [1218 ], $17.31 \%$ in CS [19-25], and $27.27 \%$ in CR [26-34]. And the overall case fatality rate of all reviewed articles was $11.21 \%(n=73)$. 
medRxiv preprint doi: https://doi.org/10.1101/2021.07.25.21260967; this version posted July 28, 2021. The copyright holder for this preprint (which was not certified by peer review) is the author/funder, who has granted medRxiv a license to display the preprint in perpetuity.

All rights reserved. No reuse allowed without permission.

Our results indicate that PLWH were a high risk group with greater than $50 \%$ needed hospitalization while $1 / 5$ of hospitalized patients needed critical care. This finding aligns with the argument that predicts a bad outcome of COVID-19 in PLWH due to immunocompromised status [14, 20] and does not support the argument predicting a better prognosis for PLWH. $[15,17,18,19]$ The better prognosis could be explained by a lower risk for cytokine storm as a result of immunodeficiency, as there are low CD4 T lymphocytes which are responsible for activating innate immune cells like B-lymphocytes, cytotoxic T cells, and non-immune cells. There is also some suppression of the immune reaction through subtype T helper cells. [35]

Correlation analysis of CD4+ counts with hospitalization and mortality were not consistent in all reviewed studies as it showed weak positive in case series and case reports while weak negative in cohorts [12, 1418]. And in mortality, there was a weak negative correlation in cohorts and case series [19-25] while weak positive in case reports [26-34]. More studies needed to focus on this to determine if CD4+ counts strongly correlate with the outcome of COVID-19.

We found that PLWH and confirmed COVID-19 do not present differently than the rest of the population as the common clinical presentations are cough (28.2\%), fever (27.3\%), and shortness of breath (10.8\%), which is consistent with the finding of cohorts [12,14, 16-18] and case series [19-25].

Analyzing the available data for deceased patients, we found the age range to be between 47 and 82 with a male to female ratio of $3: 1$, this correlates with the general population as data reveal that males had a mortality rate more than females. [37] The comorbidity data of deaths were available for 26 deceased individuals: HTN (no=9), DM (no=6), COPD (no=3), CKD (no=8), ESRD (no=1), CVD/CHF (no=2), organ transplant (no=1), prior stroke (no=2), cancer $(n o=2)$, liver cirrhosis $(n o=1)$, and obesity (no=3). The CD4+ counts ranged from below 50 to 800 . The average CD4+ counts for Ho et al. [14], Meyerowitz et al. [16], and Harter et al. [18] of the deaths the cohort studies were 686, 426, and 389, respectively, and mortality rates in these cohorts were $20.5 \%, 5.6 \%$, and $9.1 \%$, respectively.

Nearly $98 \%$ of the cohort and $95 \%$ of the case series patients were being treated with ART at the time of diagnosis. According to Del Amo et al.[13], HIV-positive patients who were receiving TDF/FTC had a lower risk of contracting COVID-19 and ultimately being hospitalized, concluding that further investigation is necessary. However, Kate Child et al [20] concluded that patients on suppressive ART were not protected from moderate or severe COVID-19. We could not find any correlation between a specific type of ART and the risk of hospitalization, ICU admission, or mortality.

Despite the fact that this review was done following a standardized methodology, it presents with specific limitations. Cohort studies that we reviewed, such as Del Amo et al. and Meyerowitz et al. did not report an HIV viral load which makes it difficult to assess in relation to the other cohorts. Del Amo et al. also did not disclose a CD4+ count. Among the case reports, the HIV viral load and the total number of patients on IMV were not reported by Maomao et al. Lastly, Byrd et al. did not present the total number of patients admitted in the ICU and the number of patients on IMV. We did not run a study assessment because these limitations create barriers which make it hard to assess and compare the studies with one another.

\section{Conclusion:}

In conclusion, our results indicate that PLWH with COVID-19 are at increased risk for hospitalization, ICU admission, IMV requirement and mortality. We recommend classifying this group as high risk and they should adhere strictly to COVID-19 precautions. Authors conclude that larger sample size and study 
medRxiv preprint doi: https://doi.org/10.1101/2021.07.25.21260967; this version posted July $28,2021$. The copyright holder for this preprint (which was not certified by peer review) is the author/funder, who has granted medRxiv a license to display the preprint in perpetuity.

All rights reserved. No reuse allowed without permission.

volume is needed to fully evaluate the outcome of this novel virus and confirm the association of CD4+cell counts with severe forms of the disease and mortality.

\section{References:}

1. Listings of WHO's response to COVID-19. Who.int. https://www.who.int/news-room/detail/2906-2020-covidtimeline. Accessed June 20, 2020.

2. Zhu N, Zhang D, Wang W, et al. A Novel Coronavirus from Patients with Pneumonia in China, 2019. N Engl J Med. 2020;382(8):727-733. doi:10.1056/NEJMoa2001017

3. Zhou P, Yang XL, Wang XG, et al. A pneumonia outbreak associated with a new coronavirus of probable bat origin. Nature. 2020;579(7798):270-273. doi:10.1038/s41586-020-2012-7

4. Kankyokansen.org. http://www.kankyokansen.org/uploads/uploads/files/isipc/protocol V7.pdf.

Accessed September 15, 2020

5. Carrillo-Larco RM, Altez-Fernandez C. Anosmia and dysgeusia in COVID-19: A systematic review. Wellcome Open Res. 2020;5:94. Published 2020 May 13. doi:10.12688/wellcomeopenres.15917.1

6. Huang $\mathrm{C}$, Wang $\mathrm{Y}, \mathrm{Li} \mathrm{X}$, et al. Clinical features of patients infected with 2019 novel coronavirus in Wuhan, China [published correction appears in Lancet. 2020 Jan 30;:]. Lancet. 2020;395(10223):497-506. doi:10.1016/S0140-6736(20)30183-5

7. Cheng $\mathrm{Y}$, Luo $\mathrm{R}$, Wang $\mathrm{K}$, et al. Kidney disease is associated with in-hospital death of patients with COVID-19. Kidney Int. 2020;97(5):829-838. doi:10.1016/j.kint.2020.03.005

8. Lauer SA, Grantz KH, Bi Q, et al. The Incubation Period of Coronavirus Disease 2019 (COVID-19) From Publicly Reported Confirmed Cases: Estimation and Application. Ann Intern Med. 2020;172(9):577-582. doi:10.7326/M20-0504

9. Wu Zhang X, Leng Yap Y. Structural similarity between HIV-1 gp41 and SARS-CoV S2 proteins suggests an analogous membrane fusion mechanism. Theochem. 2004;677(1):73-76. doi:10.1016/j.theochem.2004.02.018

10. Lopinavir/Ritonavir and Other HIV Protease Inhibitors | Coronavirus Disease COVID-19. Nih.gov. https://www.covid19treatmentguidelines.nih.gov/antiviral-therapy/lopinavir-ritonavir-andother-hiv-protease-inhibitors/. Accessed July 17, 2020.

11. Ssentongo P, Ssentongo AE, Heilbrunn ES, Ba DM, Chinchilli VM. Association of cardiovascular disease and 10 other pre-existing comorbidities with COVID-19 mortality: A systematic review and meta-analysis. PLoS One. 2020 Aug 26;15(8):e0238215. doi: 10.1371/journal.pone.0238215. PMID: 32845926; PMCID: PMC7449476.

12. Vizcarra P, Pérez-Elías MJ, Quereda C, et al. Description of COVID-19 in HIV-infected individuals: a single-centre, prospective cohort. Lancet HIV. 2020;7(8):e554-e564. doi:10.1016/S23523018(20)30164-8

13. Del Amo J, Polo R, Moreno S, et al. Incidence and Severity of COVID-19 in HIV-Positive Persons Receiving Antiretroviral Therapy: A Cohort Study [published online ahead of print, 2020 Jun 26]. Ann Intern Med. 2020;M20-3689. doi:10.7326/M20-3689

14. Ho HE, Peluso MJ, Margus C, et al. Clinical outcomes and immunologic characteristics of Covid-19 in people with HIV [published online ahead of print, 2020 Jun 30]. J Infect Dis. 2020;jiaa380. doi:10.1093/infdis/jiaa380

15. Sigel K, Swartz T, Golden E, et al. Covid-19 and People with HIV Infection: Outcomes for Hospitalized Patients in New York City [published online ahead of print, 2020 Jun 28]. Clin Infect Dis. 2020;ciaa880. doi:10.1093/cid/ciaa880

16. Meyerowitz EA, Kim AY, Ard KL, et al. Disproportionate burden of coronavirus disease 2019 among racial minorities and those in congregate settings among a large cohort of people with HIV. AIDS. 2020;34(12):1781-1787. doi:10.1097/QAD.0000000000002607 
medRxiv preprint doi: https://doi.org/10.1101/2021.07.25.21260967; this version posted July $28,2021$. The copyright holder for this preprint (which was not certified by peer review) is the author/funder, who has granted medRxiv a license to display the preprint in perpetuity.

All rights reserved. No reuse allowed without permission.

17. Gervasoni C, Meraviglia P, Riva A, et al. Clinical features and outcomes of HIV patients with coronavirus disease 2019 [published online ahead of print, 2020 May 14]. Clin Infect Dis. 2020;ciaa579. doi:10.1093/cid/ciaa579

18. Härter G, Spinner CD, Roider J, et al. COVID-19 in people living with human immunodeficiency virus: a case series of 33 patients [published online ahead of print, 2020 May 11]. Infection. 2020;1-6. doi:10.1007/s15010-020-01438-z

19. Blanco JL, Ambrosioni J, Garcia F, et al. COVID-19 in patients with HIV: clinical case series. Lancet HIV. 2020;7(5):e314-e316. doi:10.1016/S2352-3018(20)30111-9

20. Childs K, Post FA, Norcross C, et al. Hospitalized patients with COVID-19 and HIV: a case series [published online ahead of print, 2020 May 27]. Clin Infect Dis. 2020;ciaa657. doi:10.1093/cid/ciaa657

21. Ridgway JP, Farley B, Benoit JL, et al. A Case Series of Five People Living with HIV Hospitalized with COVID-19 in Chicago, Illinois. AIDS Patient Care STDS. 2020;34(8):331-335. doi:10.1089/apc.2020.0103

22. Byrd KM, Beckwith CG, Garland JM, et al. SARS-CoV-2 and HIV coinfection: clinical experience from Rhode Island, United States. J Int AIDS Soc. 2020;23(7):e25573. doi:10.1002/jia2.25573

23. Altuntas Aydin O, Kumbasar Karaosmanoglu H, Kart Yasar K. HIV/SARS-CoV-2 coinfected patients in Istanbul, Turkey [published online ahead of print, $2020 \mathrm{Apr}$ 29]. J Med Virol. 2020;10.1002/jmv.25955. doi:10.1002/jmv.25955

24. Marimuthu J, Kumar BS, Aravind Gandhi P. HIV and SARS CoV-2 co-infection: A retrospective, record based, case series from South India [published online ahead of print, $2020 \mathrm{Jul}$ 7]. J Med Virol. 2020;10.1002/jmv.26271. doi:10.1002/jmv.26271

25. Calza L, Bon I, Tadolini M, et al. COVID-19 in patients with HIV-1 infection: a single-centre experience in northern Italy [published online ahead of print, 2020 Aug 3]. Infection. 2020;1-5. doi:10.1007/s15010-020-01492-7

26. Zhu F, Cao Y, Xu S, Zhou M. Co-infection of SARS-CoV-2 and HIV in a patient in Wuhan city, China. J Med Virol. 2020;92(6):529-530. doi:10.1002/jmv.25732

27. Zhao J, Liao $\mathrm{X}$, Wang $\mathrm{H}$, et al. Early virus clearance and delayed antibody response in a case of COVID-19 with a history of co-infection with HIV-1 and HCV [published online ahead of print, 2020 Apr 9]. Clin Infect Dis. 2020;ciaa408. doi:10.1093/cid/ciaa408

28. Wang M, Luo L, Bu H, Xia H. One case of coronavirus disease 2019 (COVID-19) in a patient coinfected by HIV with a low CD4+ T-cell count. Int J Infect Dis. 2020;96:148-150. doi:10.1016/j.ijid.2020.04.060

29. Mahmood K, Rashed ER, Oliveros E, et al. Predisposition or Protection?: COVID-19 in a Patient on LVAD Support With HIV/AIDS. JACC Case Rep. 2020;2(9):1337-1341. doi:10.1016/j.jaccas.2020.05.015

30. Toombs JM, Van den Abbeele K, Democratis J, Merricks R, Mandal AKJ, Missouris CG. COVID-19 in three people living with HIV in the United Kingdom [published online ahead of print, 2020 Jun 15]. J Med Virol. 2020;10.1002/jmv.26178. doi:10.1002/jmv.26178

31. Baluku JB, Mwebaza S, Ingabire G, Nsereko C, Muwanga M. HIV and SARS-CoV-2 coinfection: A case report from Uganda [published online ahead of print, 2020 May 21]. J Med Virol. 2020;10.1002/jmv.26044. doi:10.1002/jmv.26044

32. Nakamoto T, Kutsuna S, Yanagawa $Y$, et al. A case of SARS-CoV-2 infection in an untreated HIV patient in Tokyo, Japan [published online ahead of print, 2020 Jun 3]. J Med Virol. 2020;10.1002/jmv.26102. doi:10.1002/jmv.26102

33. Haddad S, Tayyar R, Risch L, et al. Encephalopathy and seizure activity in a COVID-19 well controlled HIV patient. IDCases. 2020;21:e00814. Published 2020 May 16. doi:10.1016/j.idcr.2020.e00814 
medRxiv preprint doi: https://doi.org/10.1101/2021.07.25.21260967; this version posted July 28, 2021. The copyright holder for this preprint (which was not certified by peer review) is the author/funder, who has granted medRxiv a license to display the preprint in perpetuity. All rights reserved. No reuse allowed without permission.

34. Menghua W, Xin Z, Jianwei L, Yu Z, Qinwei Y. Case report: one case of coronavirus disease 2019 (COVID-19) in a patient co-infected by HIV with a normal CD4+ T cell count. AIDS Res Ther. 2020;17(1):46. Published 2020 Jul 23. doi:10.1186/s12981-020-00301-3

35. Mascolo, S., Romanelli, A., Carleo, M.A. and Esposito, V. (2020), Could HIV infection alter the clinical course of SARS-CoV-2 infection? When less is better. J Med Virol, 92: 1777-1778. doi:10.1002/jmv.25881

36. Luckheeram RV, Zhou R, Verma AD, Xia B. CD4 ${ }^{+}$T cells: differentiation and functions. Clin Dev Immunol. 2012;2012:925135. doi:10.1155/2012/925135

37. Zheng Z, Peng F, Xu B, Zhao J, Liu H, Peng J, Li Q, Jiang C, Zhou Y, Liu S, Ye C, Zhang P, Xing Y, Guo $\mathrm{H}$, Tang W. Risk factors of critical \& mortal COVID-19 cases: A systematic literature review and meta-analysis. J Infect. 2020 Aug;81(2):e16-e25. doi: 10.1016/j.jinf.2020.04.021. Epub 2020 Apr 23. PMID: $32335169 ;$ PMCID: PMC7177098

Author/Study type
Location

Total no. infect. pts
Total no. hosp. pts
Rate of hosp.
Total no. ICU pt.
ICU rate (total

pt., hosp.)
Total no. IMV pt.
Rate of IMV (total pt., hosp., ICU)

\section{Viscarra et al/ Prospective \\ Del Amo et al/Prospective \\ Ho et al/ Retrospective \\ Sigel et al / Retrospective \\ Meyerowitz et al / Retrospective

Spain

Spain

USA

USA

USA

Italy
35

28

236

93

72

88

36

21

$50 \%$

13

28

88

$100 \%$
6

15

19

18

6

$\%$

$28.6 \%, 16.6 \%$

$28.6 \%, 16.6 \%$

$15.4 \%, 7.1 \%$
5

NA

15

18

4

$11.1 \%, 19.1 \%$ 
medRxiv preprint doi: https://doi.org/10.1101/2021.07.25.21260967; this version posted July 28, 2021. The copyright holder for this preprint (which was not certified by peer review) is the author/funder, who has granted medRxiv a license to display the preprint in perpetuity. All rights reserved. No reuse allowed without permission.

\begin{tabular}{|c|c|c|c|c|c|c|c|c|}
\hline $\begin{array}{l}\text { Harter et al / } \\
\text { Retrospective }\end{array}$ & Germany & 33 & 14 & $42 \%$ & 6 & $42.9 \%, 18.2 \%$ & 4 & $12.1 \%, 28.6 \%$ \\
\hline Total & & 549 & 387 & $70.49 \%$ & 72 & $\begin{array}{l}13.11 \%, \\
18.61 \%\end{array}$ & 48 & $\begin{array}{c}8.74 \%, 12.70 \%, \\
66.67 \%\end{array}$ \\
\hline
\end{tabular}

Table 1. Outcome of PLWH with COVID-19: Cohort Studies

\begin{tabular}{|c|c|c|c|c|c|c|c|c|}
\hline $\begin{array}{r}\text { Author/Study } \\
\text { type }\end{array}$ & Location & $\begin{array}{l}\text { Total no. } \\
\text { infect pts. }\end{array}$ & $\begin{array}{l}\text { Total no. } \\
\text { hosp. pts }\end{array}$ & $\begin{array}{l}\text { Rate of } \\
\text { hosp }\end{array}$ & $\begin{array}{l}\text { Total no. ICU } \\
\text { pts }\end{array}$ & $\begin{array}{c}\text { ICU rate (total pt., } \\
\text { hosp.) }\end{array}$ & $\begin{array}{l}\text { Total no. } \\
\text { IMV pts. }\end{array}$ & $\begin{array}{l}\text { Rate of IMV } \\
\text { (total pt., } \\
\text { hosp., ICU) }\end{array}$ \\
\hline $\begin{array}{r}\text { Blanco et al / } \\
\text { Case Series }\end{array}$ & Spain & 5 & 5 & $100 \%$ & 2 & $40 \%, 40 \%$ & 1 & $20 \%, 20 \%$ \\
\hline $\begin{array}{c}\text { Childs et al / } \\
\text { Case Series }\end{array}$ & USA & 18 & 18 & $100 \%$ & 5 & $27.7 \%, 27.7 \%$ & 5 & $27.78 \%, 27.8 \%$ \\
\hline $\begin{array}{r}\text { Ridgeway et al } \\
\text { / Case Series }\end{array}$ & USA & 5 & 5 & $100 \%$ & 1 & $20 \%, 20 \%$ & 0 & 0 \\
\hline $\begin{array}{l}\text { Byrd et al / } \\
\text { Case Series }\end{array}$ & USA & 27 & 9 & $33.30 \%$ & 0 & 0 & 0 & 0 \\
\hline $\begin{array}{r}\text { Altuntas Aydin } \\
\text { et al / Case } \\
\text { Series }\end{array}$ & Turkey & 4 & 4 & $100 \%$ & 1 & $25 \%, 25 \%$ & 1 & $25 \%, 25 \%$ \\
\hline $\begin{array}{l}\text { Marimuthu et } \\
\text { al / Case Series }\end{array}$ & India & 6 & 6 & $100 \%$ & 0 & 0 & 0 & 0 \\
\hline
\end{tabular}


medRxiv preprint doi: https://doi.org/10.1101/2021.07.25.21260967; this version posted July 28, 2021. The copyright holder for this preprint (which was not certified by peer review) is the author/funder, who has granted medRxiv a license to display the preprint in perpetuity. All rights reserved. No reuse allowed without permission.

\begin{tabular}{|c|c|c|c|c|c|c|c|c|}
\hline $\begin{array}{l}\text { Calza et al / } \\
\text { Case Series }\end{array}$ & Italy & 26 & 5 & $19.20 \%$ & 0 & 0 & 0 & 0 \\
\hline Total & & 91 & 52 & $57.14 \%$ & 9 & $9.89 \%, 17.31 \%$ & 7 & $\begin{array}{c}7.69 \%, 13.46 \% \\
77.78 \%\end{array}$ \\
\hline
\end{tabular}

Table 2. Outcome of PLWH with COVID-19: Case Series

\begin{tabular}{|c|c|c|c|c|c|c|c|c|}
\hline $\begin{array}{r}\text { Author/Study } \\
\text { type }\end{array}$ & Location & $\begin{array}{l}\text { Total no. } \\
\text { infected pts }\end{array}$ & $\begin{array}{l}\text { Total no. hosp. } \\
\text { pts }\end{array}$ & $\begin{array}{l}\text { Rate of } \\
\text { hosp. }\end{array}$ & $\begin{array}{l}\text { Total no. } \\
\text { ICU pt. }\end{array}$ & $\begin{array}{l}\text { ICU rate (total } \\
\text { pt., hosp.) }\end{array}$ & $\begin{array}{c}\text { Total } \\
\text { no. IMV } \\
\text { pt. }\end{array}$ & $\begin{array}{c}\text { Rate of IMV } \\
\text { (total pt., } \\
\text { hosp., ICU) }\end{array}$ \\
\hline
\end{tabular}

\begin{tabular}{|c|c|c|c|c|c|c|c|c|}
\hline $\begin{array}{r}\text { Zhu et al / Case } \\
\text { Report }\end{array}$ & China & 1 & 1 & $100 \%$ & 0 & 0 & 0 & 0 \\
\hline $\begin{array}{r}\text { Zhao et al / Case } \\
\text { Report }\end{array}$ & USA & 1 & 1 & $100 \%$ & 0 & 0 & 0 & 0 \\
\hline $\begin{array}{l}\text { Wang et al / } \\
\text { Case Report }\end{array}$ & China & 1 & 1 & $100 \%$ & 1 & $100 \%, 100 \%$ & 0 & 0 \\
\hline $\begin{array}{l}\text { Kiran Rashed et } \\
\text { al / Case Report }\end{array}$ & USA & 1 & 1 & $100 \%$ & 0 & 0 & 0 & 0 \\
\hline $\begin{array}{l}\text { Toombs et al / } \\
\text { Case Report }\end{array}$ & UK & 3 & 3 & $100 \%$ & 1 & $33.3 \%, 33.3 \%$ & 1 & $\begin{array}{c}33.3 \%, 33.3 \% \\
100 \%\end{array}$ \\
\hline $\begin{array}{r}\text { Baluku et al / } \\
\text { Case Report }\end{array}$ & Uganda & 1 & 1 & $100 \%$ & 0 & 0 & 0 & 0 \\
\hline $\begin{array}{r}\text { Nakamoto et al } \\
\text { / Case Report }\end{array}$ & Japan & 1 & 1 & $100 \%$ & 0 & 0 & 0 & 0 \\
\hline $\begin{array}{r}\text { Hadded et al/ } \\
\text { Case Report }\end{array}$ & USA & 1 & 1 & $100 \%$ & 1 & $100 \%, 100 \%$ & 1 & $100 \%, 100 \%$ \\
\hline
\end{tabular}


medRxiv preprint doi: https://doi.org/10.1101/2021.07.25.21260967; this version posted July 28, 2021. The copyright holder for this preprint (which was not certified by peer review) is the author/funder, who has granted medRxiv a license to display the preprint in perpetuity. All rights reserved. No reuse allowed without permission.

\begin{tabular}{|c|c|c|c|c|c|c|c|c|}
\hline $\begin{array}{r}\text { Menghua et al / } \\
\text { Case Report }\end{array}$ & China & 1 & 1 & $100 \%$ & 0 & 0 & 0 & 0 \\
\hline Total & & 11 & 11 & $100 \%$ & 3 & $27.27 \%$ both & 2 & $\begin{array}{l}18.18 \% \\
18.18 \% \\
66.67 \%\end{array}$ \\
\hline
\end{tabular}

Table 3. Outcome of PLWH with COVID-19: Case Reports

Table 4. Mortality data from all reviewed articles

\begin{tabular}{|c|c|c|c|}
\hline Author (no. death) & $\begin{array}{l}\text { Age (mean) } \\
\text { Gender }\end{array}$ & Comorbidities & ART \\
\hline Viscarr et al $(\mathrm{no}=2)$ & $\mathrm{N} / \mathrm{A}$ & N/A & $\mathrm{N} / \mathrm{A}$ \\
\hline Del Amo et al $(\mathrm{no}=\mathbf{2 0})$ & $\begin{array}{c}\mathrm{N} / \mathrm{A} \\
16 \mathrm{~m}, 4 \mathrm{f}\end{array}$ & N/A & $\begin{array}{l}-10 \text { pt. on TAF/FTC } \\
-8 \text { pt. on } A B C / 3 T C\end{array}$ \\
\hline Ho et al $(n o=19)$ & $\begin{array}{c}62(55-68) \\
13 m, 6 f\end{array}$ & 13 obesity & $\begin{array}{l}-10 \text { pt. on TDF } \\
-3 \text { pt. on } \mathrm{PI}\end{array}$ \\
\hline Sigel et al $(\mathrm{no}=18)$ & $\begin{array}{c}62(57-67) \\
13 \mathrm{~m}, 5 \mathrm{f}\end{array}$ & 4 DM, 6 HTN, 2 COPD, 6 CKD, 3 organ transplant, 1 liver cirrhosis, 1 obesity & $\begin{array}{c}-13 \text { pt. on Integrase } \\
-5 \text { pt. on PI } \\
-16 \text { pt. on NRT }\end{array}$ \\
\hline Meyerowitz et al (no= 2) & $\begin{array}{l}59,63 \\
1 \mathrm{~m}, 1 \mathrm{f}\end{array}$ & $\begin{array}{c}\text { 1st pt.: CHF, CKD, DM, HLD, HTN, prior stroke, } 40 \mathrm{BMI} \\
\text { 2nd pt.: HTN, prior stroke, CKD }\end{array}$ & $\begin{array}{l}\text {-1st pt.: } C T G+A B C / E T G+D R T / r+E T R \\
-2 n d \text { pt.: DTG+TAF/FTC }\end{array}$ \\
\hline Gervasoni et al $(\mathrm{no}=\mathbf{2})$ & $\begin{array}{l}47, \mathrm{~N} / \mathrm{A} \\
2 \mathrm{~m}\end{array}$ & $\begin{array}{l}\text {-1st pt.: obesity } \\
-2 \text { d pt.: CVD, lung cancer }\end{array}$ & N/A \\
\hline
\end{tabular}


medRxiv preprint doi: https://doi.org/10.1101/2021.07.25.21260967; this version posted July 28, 2021. The copyright holder for this preprint (which was not certified by peer review) is the author/funder, who has granted medRxiv a license to display the preprint in perpetuity.

All rights reserved. No reuse allowed without permission.

\begin{tabular}{|c|c|c|c|}
\hline Harter et al $(\mathrm{no}=3)$ & $\begin{array}{c}59,55,82 \\
3 \mathrm{~m}\end{array}$ & $\begin{array}{c}-1 \text { pt.: } \mathrm{HTN}, \mathrm{COPD}, \mathrm{DM} \\
\text {-other 2: N/A }\end{array}$ & $\begin{array}{l}\text {-1st pt.: DOR/TDF, } \\
\text {-2nd pt.: BIC/TAF/ } \\
\text {-3rd pt.: DRV/RTV }\end{array}$ \\
\hline Byrd et al $(\mathrm{no}=1)$ & $\begin{array}{l}59 \\
\mathrm{~m}\end{array}$ & ESRD, cancer & $\mathrm{EFV}, \mathrm{ABC}$ \\
\hline
\end{tabular}




\section{Viscarra et al (no=35)}

Sigel et al (no= 88)

Gervasoni et al (no= 28)

Blanco et al $(n o=5)$

Childs et al (no= 18)

Ridgeway et al (no=5)

Del Amo et al (no= 236)

al (no= 36$)$

Harter et al (no=33)
15 (42.9\%) HTN, $10 \%)$ CVD, 6 (17.1\%) DM, 3 (8.6\%) CKD, 16 (45.7\%)chronic liver disease, 8 (22.9\%)chronic respiratory disease, 9 (25.7\%) cancer
25 fever, 7 sore throat, 24 cough, 21 dyspnea, 4 anosmia/ageusia, 13 myalgia, 8 headache, 21 fatigue, 10 diarrhea, $3 \mathrm{~N} / \mathrm{V}$
34 pt.: $<50$

$502(295-771)$

$\mathrm{Y} / 100 \%$

49 (52.7\%) HTN, 32 (34.4\%) DM, 25 (26.8\%) COPD/Asthma, 16 (17.2\%) CKD, 8 (8.6\%) cancer, 7 (7.5\%) ESRD, 4 (4.3\%) autoimmune disease

33 (37.5\%) HTN, 24 (27.3\%) DM, 5 (5.7\%) N/A 61 fever, 71 cough, 57 SOB, 10 altered mental status

$\begin{array}{lll}\text { N/A } & \text { N/A } & \text { N/A }\end{array}$

57 pt.: $<50$

$554(339-752)$
-66 pt.: $<50$

$<50->500$
$\mathrm{Y} / 100 \%$
$\mathrm{Y} / 95.7 \%$ liver cirrhosis, 6 (6.8\%) CAD, 19 (21.6\%) CKD, 15 (17.1\%) cancer, 4 (4.6\%) organ transplant, 9 (10.2\%) obesity, 48 (54.6\%) smoking
11 (30.6\%) HTN, 8 (22.2\%) DM, 4 ( 11.1\% CHF, 8 (22.2\%) HLD, 6 (16.7\%) CKD, 2 (5.6\%) ESRD, 5 (13.9\%) stroke, 3 (8.3\%) COPD, 3 (8.3\%) smoking, 1 (2.8\%) NASH, 1 (2.8\%) NAFLD, 1 (2.8\%) asthma, 1 (2.8\%) dementia, 2 (5.6\%) lymphomas (in remission)
22 fever, 21 cough, 6 sore throat, 8 myalgia, 5 fatigue, 3 dyspnea, 13 SOB, 10 myalgia, 4 headache, 3 altered mental status, 4 anosmia/ageusia, $7 \mathrm{GI}$ (diarrhea, appetite loss, N/V),3 congestion
-16 pt.: $>50$
1 (20\%) hypothyroidism, 1 (20\%) asthma, 3 none
14 (50\%) HTN, 3 (10.7\%) DM, 15 (53.6\%) HLD, 5 (17.9\%) HCV/HBV co-infection, 4 $(14.3 \%)$ renal disease, $2(7.1 \%)$ epilepsy, 2 (7.1\%) CVD, 3 (10.7\%) neoplasm, 2

10 (30.3\%) HTN, 4 (12.1\%) DM, 6 (18.2\%) COPD, 2 (6.1\%) CVD, 2 (6.1\%) renal disease, 5 (15.2\%) HBV, 3 (9.1\%) CVD, 1 (3\%) HCV (7.1\%) COPD, 1 (3.6\%) organ transplant
41 fever, 23 cough, 10 dyspnea, 7 diarrhea, 4 myalgia, 3 headaches
N/A

$691(16-1485)$

$\mathrm{Y} / 97.2 \%$

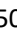

$636(346-926)$

$\mathrm{Y} / 100 \%$
25 cough, 22 fever, 7 myalgia/arthralgia, 7 headache, 7 sore throat, 6 anosmia
-30 pt.: $<50$

$-920$
$-824$
5 fever, 5 cough, 4 malaise/headache, 1 dyspnea
4 pts $<50$;

1pt. 45,500
563.7

$\mathrm{Y} / 80 \%$
6 (33.3\%) HTN, 4 (22.2\%)DM, 5 (27.8\%)

CKD, 10 (55.6\%) obesity

2 (40\%)HTN, 1 (20\%) DM, 1 (20\%) HLD, 3 (60\%) obesity, 1 (20\%) OSA, 1 (20\%) TB, 1

(20\%) Addison's dis, 1 CHF, 1 COPD, 1 PE
11 Fever, 13 cough, 12 SOB

$<50$

20

3 fever, 4 cough, 3 SOB; 3 diarrhea, 2 myalgia, 2 headache, $2 \mathrm{n} / \mathrm{V}, 1$ abd pain, 1 chest pain, 1 dyspnea 


\section{Altuntas aydin} et al $(n o=4)$

Marimuthu et al $(n o=6)$

Calza et al (no=

Zhu et al (no=

1)

Zhao et al (no=

1)

Wang et al (no= 1)

Kiran Rashed et al $(n o=1)$

Toombs et al (no=3)

Baluku et al (no= 1)

Nakamoto et al (no= 1)

Hadded et al (no= 1)

Menghua et al (no=1)
N/A

cough, dyspnea, lethargy, fever headache, sore throats, chest pain,

myalgia, anosmia

1 (25\%) DM, 1 (25\%) COPD, 1 (25\%) HTN,

1 (25\%) HBV, 1 (25\%) bipolar disorder, 1

(25\%) obesity (35.5 BMI)

2 (33.3\%) HTN

$\mathrm{Y} / 83.3 \%$

11 (42.3\%) HTN, 4 (15.4\%) DM, 4 (15.4\%) obesity, 3 (11.5\%) asthma / chronic respiratory disease, 3 (11.5\%)

hypothyroidisms
5 fever, 2 cough, 1 sore throat

N/A

535

19 Fever, 14 cough, 11 fatigue, 11

$<50$

350

$\mathrm{Y} / \mathrm{n} / \mathrm{a}$

N/A

627

Y/100\% myalgia, 3 dyspnea, 4 tachypnea
$87-1441$

$\mathrm{Y} / \mathrm{n} / \mathrm{a}$
DM2, smoker

Fever, cough, SOB

N/A

N/A

None

Fever, myalgia

$<500$

Fever, cough, chest pain

N/A

34

Und.

266

$\mathrm{Y} / 100 \%$

CAD, DM

2 (66.7\%) DM, 2 (66.7\%) HTN, 2 (66.7\%)

smoker, 1 (33.3\%) TB, 1 (33.3\%) obesity, 1

(33.3\%) Graves' disease

2 Fever, 3 cough, 2 dyspnea, 1

headache, 1 anorexia

-2 pt.: und.

373

$\mathrm{Y} / 100 \%$

-1 pt.: $1,000,000$
N/A

HBV, syphilis

None

h/o syphilis (cured)
Headache, chest pain, myalgia,

anorexia

Cough

Fever, cough, altered mental status,

GI (vomiting. Abd. pain)

Fatigue

Und.
Y/100\%

Und.

604

$\mathrm{Y} / 100 \%$
N/A 
medRxiv preprint doi: https://doi.org/10.1101/2021.07.25.21260967; this version posted July 28, 2021. The copyright holder for this preprint (which was not certified by peer review) is the author/funder, who has granted medRxiv a license to display the preprint in perpetuity.

All rights reserved. No reuse allowed without permission.

Table 5. Patient Characteristics of all reviewed articles (comorbidity, CD4 counts, viral load) 